\title{
Observations on the reproductive cycle, age and growth of the salema, Sarpa salpa (Osteichthyes: Sparidae) along the western central coast of Italy*
}

\section{ALESSANDRO CRISCOLI, FRANCESCO COLLOCA, PAOLO CARPENTIERI, ANDREA BELLUSCIO and GIANDOMENICO ARDIZZONE}

Dipartimento di Biologia Animale e dell’Uomo, Università "La Sapienza” di Roma, Viale dell'Università 32, 00185 Rome, Italy E-mail: alecriscoli@fastwebnet.it

SUMMARY: The sexual maturation and the growth of the salema, Sarpa salpa (Linnaeus, 1758), along the Italian Mediterranean coast (central Italy), were studied in fish $(\mathrm{n}=105)$ killed incidentally by underwater explosions during the construction of Civitavecchia harbour in 1999 and specimens collected with trammel nets $(\mathrm{n}=339)$. This species is characterized by a protandric hermaphroditism and the sex change process occurs between 24 and $31 \mathrm{~cm}$ TL corresponding to a wide range of ages (3-7 years). Size at maturity $\left(\mathrm{L}_{50}\right)$ was $19.5 \mathrm{~cm}$, at which almost all the individuals were males. Two distinct spawning periods were observed: one in spring, from March to May, and the other in autumn, from the end of September to November. During the first year, compensatory growth occurred in the individuals born in the two periods. An annual regular pattern of ring deposition was identified in the otoliths: the translucent ring was laid down during the winter months, while the opaque ring was formed during the summer months. Back-calculated lengths at age were used to estimate the parameters of the Von Bertalanffy growth equation which were: $\mathrm{L}_{\infty}=37.27 \mathrm{~cm}, \mathrm{~K}=0.27$ year-1 and $\mathrm{t}_{0}=-0.53$ year. Salema showed isometric growth $(\mathrm{b}=3.04 ; \mathrm{P}=0.84 ; \mathrm{t}=0.19)$.

Keywords: reproduction, protandrous, lengths-at-age, otoliths.

RESUMEN: PATRÓN REPRODUCTIVO Y CARACTERÍSTICAS DE LA POBLACIÓN DE LA SALEMA, SARPA SALPA (OSTEICHTHYES: SparidAe) EN El MAR MediterRáNeO. - La maduración sexual y crecimiento de Sarpa salpa (Linnaeus, 1758) en las costas del Mediterráneo italiano (Italia central) fueron estudiadas a partir de la recolecta de ejemplares muertos accidentalmente (n = 105) como consecuencia de las explosiones submarinas acaecidas durante la construcción del puerto de Civitavecchia en 1999, así como de ejemplares recolectados mediante redes de arrastre $(n=339)$. Esta especie se caracteriza por un hermafroditismo protándrico, ocurriendo el proceso de cambio sexual entre los 24 y $31 \mathrm{~cm}$ TL, los cuales corresponden a un amplio rango de edades (3-7 años). La talla de maduración $\left(\mathrm{L}_{50}\right)$ fue de 19,5 cm, siendo la casi la totalidad de los individuos eran de sexo masculino. Se observaron dos períodos diferentes de reproducción: uno en primavera, de marzo a mayo y otro en otoño, de finales de septiembre a noviembre. Se observó, durante el primer año, un crecimiento compensatorio ocurrido entre los individuos nacidos en los dos períodos. Se identificó en los otolitos un modelo anual y regular de deposición de anillos. Se observó el depósito de un anillo translúcido durante los meses invernales, mientras que otro opaco se formó durante los meses de verano. Las composición por edades y tallas retrocalculadas se utilizaron para estimar los parámetros de la ecuación de crecimiento de Von Bertalanffy, es decir: $\mathrm{L}_{\infty}=37,27 \mathrm{~cm}, \mathrm{~K}=0,27$ año ${ }^{-1}$ y $\mathrm{t}_{0}=-0,53$ año. $S$. salpa demostró un crecimiento isométrico $(\mathrm{b}=3,04 ; \mathrm{P}=0,84 ; \mathrm{t}=0,19)$.

Palabras clave: reproducción, proterándrico, talla-edad, otolitos. 


\section{INTRODUCTION}

Salema, Sarpa salpa (Linnaeus, 1758), is a sparid fish that lives in shallow waters, where there are rocky bottoms or seagrass beds, such as Posidonia oceanica or Cymodocea nodosa, typical of temperate and tropical areas like the Mediterranean Sea, the east Atlantic (from the Gascony gulf to South Africa), the west Indian Ocean (from South Africa to southern Mozambique) and some zones of the Black Sea. It makes up schools sometimes formed by several hundred individuals and is the main herbivorous demersal fish of the west Mediterranean (Verlaque, 1990). It feeds on algae, diatoms and macrophytes (Havelange et al., 1997). However, its larvae have a mixed diet which includes copepods and diatoms. The daily requirement of vegetable food is about $6-20 \%$ of its body weight (Gerking, 1984).

According to the terminology introduced by Hiatt and Strasburg (1960), this species can be classified as "browsers" because it uses the "bite and tear" technique for obtaining its diet (Gerking, 1994). Morphological adaptations include specialized teeth to tear the vegetable tissues (Gerking, 1994). This species is described as a protandrous hermaphrodite. The male gonadic tissue matures first and the female tissue develops later. This process is so gradual that non-functional intersexes can be observed (Lepori, 1980). Malo-Michèle (1977) stated that the presence of testicular tissue appeared to inhibit full ovarian maturation (atresia of vitellogenetic stages).

Research into Sarpa salpa has focused mainly on feeding habits (Antolic et al., 1994; Sanchez Lizaso et al., 1994; Havelange et al., 1997; Pinnegar et al., 2000), and its distribution (Dulcic et al., 1997; Francour, 1997; Ruitton et al., 2000). Information on its reproduction in Sardinian waters was given by Lissia-Frau (1966), and in Tunisian waters by Sellami and Bruslé (1975), and Anato and Ktari (1983). There are no data available on its growth for the Mediterranean population. The only studies on growth were made in the Canary Islands (MendezVillamil et al., 2001), and in the eastern South African waters (Van der Walt and Beckley, 1997).

This study aims to improve the knowledge about salema's biological parameters (growth and reproduction) because this species plays an important role in the coastal Mediterranean ecosystem in relation to its abundance and trophic ecology (Ruitton et al., 2000), and constitutes an important resource for artisanal fishery using fixed gear (trammel and gillnets).

\section{MATERIALS AND METHODS}

The study was performed along the western coasts of central Italy in an area characterized by rocky bottoms and scattered Posidonia oceanica meadows (outer boundaries: Latitude $42^{\circ} \mathrm{N}$, Longitude $11^{\circ} 50^{\prime} \mathrm{E}$; Latitude $42^{\circ} 10^{\prime} \mathrm{N}$, Longitude $\left.11^{\circ} 43^{\prime} \mathrm{E}\right)$. Shallow waters in this area are influenced by the outflow of the river Tiber and show a high level of eutrophication compared with the oligotrophic state of the western Mediterranean basin (Bortoluzzi et al., 1982).

A total of 339 specimens of salema (13.5-33.5 $\mathrm{cm}$ TL) were collected from commercial catches of small-scale vessels using trammel nets in the period from February 2000 to January 2002 (Table 1). The nets used by the local artisan fleet were generally characterised by a mesh size in the inner panel ranging from 42 to $60 \mathrm{~mm}$ (stretched mesh). Another sample of 105 individuals (9-26.5 cm TL) was collected from March 1999 to July 1999

TABLE 1.- Number of individuals, divided according to sex, caught monthly according to the method of collection.

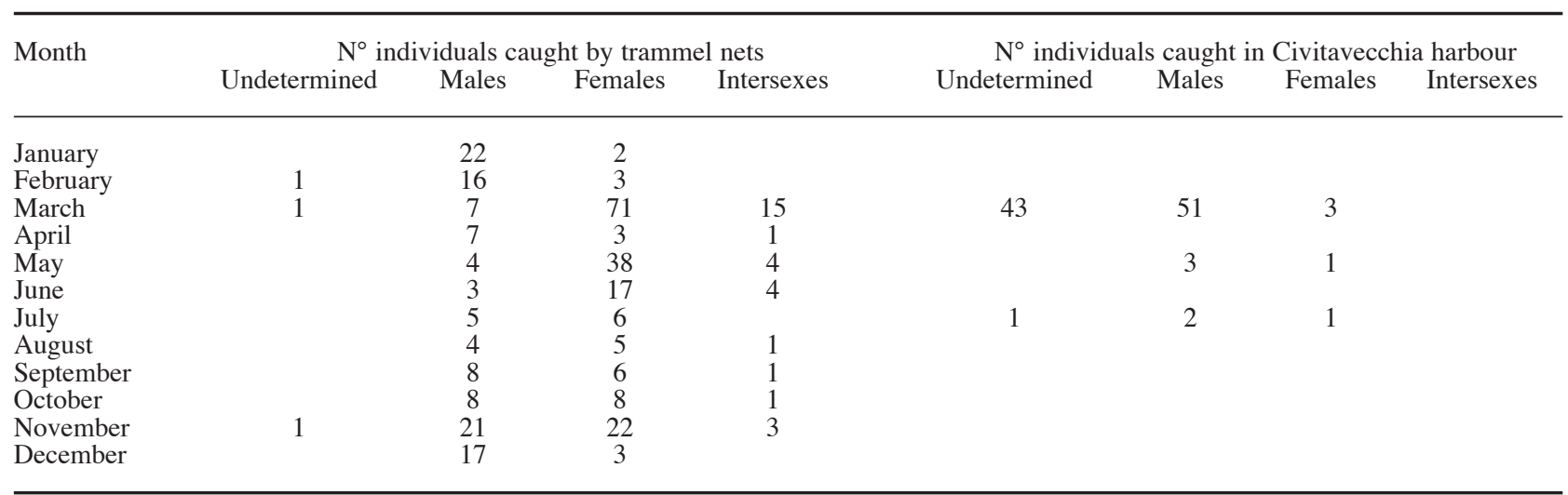


TABLE 2. - Five-point maturity scale for partial spawners (Holden and Raitt, 1974).

\begin{tabular}{|c|c|c|}
\hline Stage & State & Description \\
\hline I & Immature & $\begin{array}{l}\text { Ovary and testis about } 1 / 3 \text { rd length of body cavity. Ovaries pinkish, translucent; testis whitish. } \\
\text { Eggs not visible to naked eve. }\end{array}$ \\
\hline II & $\begin{array}{l}\text { Maturing virgin and } \\
\text { recovering spent }\end{array}$ & $\begin{array}{l}\text { Ovary and testis about } 1 / 2 \text { length of body cavity. Ovary pinkish, translucent; testis whitish, more } \\
\text { or less symmetrical. Eggs not visible to naked eye. }\end{array}$ \\
\hline III & Ripening & $\begin{array}{l}\text { Ovary and testis are about } 2 / 3 \text { rds length of body cavity. Ovary pinkish-yellow colour with granu- } \\
\text { lar appearance, testis whitish to creamy. No transparent or translucent eggs visible. }\end{array}$ \\
\hline IV & Ripe & $\begin{array}{l}\text { Ovary and testis from } 2 / 3 \text { rds to full length of body cavity. Ovary orange-pink in colour with } \\
\text { conspicuous superficial blood vessels. Large transparent, ripe eggs visible. Testis whitish- } \\
\text { creamy, soft. }\end{array}$ \\
\hline V & Spent & $\begin{array}{l}\text { Ovary and testis shrunken to about } 1 / 2 \text { length of body cavity. Walls loose. Ovary may contain } \\
\text { remnants of disintegrating opaque and ripe eggs, darkened or translucent. Testis bloodshot and } \\
\text { flabby. }\end{array}$ \\
\hline
\end{tabular}

(Table 1) in Civitavecchia harbour during underwater works for constructing a new quay that required using explosives. Due to these explosions, the individuals caught were already dead and floating on the surface.

For each fish, the total length (TL) was approximated to the nearest $\mathrm{mm}$ and the total weight (TW) to $0.1 \mathrm{~g}$. Sex (male, female, immature or intersexes) and maturity stages were analysed macroscopically and the gonad weight (GW) was approximated to $0.01 \mathrm{~g}$.

The maturity scale for partial spawners (Holden and Raitt, 1974), was used to classify the maturation stage (Table 2).

The spawning period was established following the monthly evolution of the gonadosomatic index (GSI). Only the specimens that had reached the size of first maturity were used for calculating the GSI, given by the ratio of the gonad weight $(\mathrm{GW})$ to the body weight of gutted fish (BW):

$$
\mathrm{GSI}=\mathrm{GW} \times 100 / \mathrm{BW}
$$

The size interval of sex reversal was estimated by considering the percentage of intersex specimens (individuals which were changing sex when they were caught) for length classes. These individuals were easily identified because they showed both types of gonads (male and female) simultaneously. This confirmed what Lepori (1980) observed in protandrous hermaphrodite species: a gradual regression of the male gonad which is progressively replaced by the female gonad.

The size at which $50 \%$ of the fish were mature $\left(\mathrm{TL}_{50}\right)$ was calculated using the following logistic function:

$$
\mathrm{P}_{L T}=1 / 1+\mathrm{e}^{\left(S_{1}-S_{2} L T\right)}
$$

where $\mathrm{P}_{L T}$ was the percentage of mature individuals in the length class; $S_{1}$ and $S_{2}$ are constants and $L_{50}$ was given by $\mathrm{S}_{1} / \mathrm{S}_{2}$.

Growth was studied using a length-at-age key from otoliths. Whole sagittae were placed in alcohol or water and examined by means of a stereomicroscope (10-40x magnification) using reflected light on a black dish. The opaque zones appear as white or light coloured rings, while the translucent zones appear as dark rings. A scale with fine increments was superimposed on the otolith image through a drawing tube and the appropriate measurement read directly from the scale (Hunt, 1979). Each otolith was measured on the main axis (OL: the longest distance between the anterior and posterior edges) and the distance from the core to the middle of each translucent zone was recorded.

Lengths-at-age of translucent rings were obtained for each individual using the Fraser-Lee equation modified by Campana (1990):

$$
\mathrm{L}_{a}=\mathrm{L}_{c}+\left(\mathrm{O}_{a}-\mathrm{O}_{c}\right) \cdot\left(\mathrm{L}_{c}-\mathrm{L}_{o}\right) \cdot\left(\mathrm{O}_{c}-\mathrm{O}_{o}\right)^{-1}
$$

where $\mathrm{L}_{a}$ and $\mathrm{O}_{a}$ are fish length and otolith size at age $a$ respectively; $\mathrm{L}_{c}$ and $\mathrm{O}_{c}$ are fish length and otolith size at capture respectively; $\mathrm{L}_{o}$ and $\mathrm{O}_{o}$ are fish length and otolith length at hatch respectively.

Campana (1990) demonstrated that growth variability, upon which all traditional back-calculation analyses are based, introduces a bias into the relationship between fish and otolith size. Using biological intercepts in the back-calculation of sizes reduces the errors and bias. The terms $\mathrm{L}_{o}$ and $\mathrm{O}_{o}$ represent the biological intercept, which is the beginning of the proportionality between fish and otolith growth. In many species, this point occurs at the time of hatching (Campana, 1990). In salema, larvae at hatch measure $6.5 \mathrm{~mm}$ TL as observed in the Gulf 
of Naples (Lo Bianco, 1931-1956). Otolith dimension at this length $\left(\mathrm{O}_{o}\right)$ was calculated by the relationship between otolith length and fish length through a linear regression.

Lengths-at-age were then used to estimate the parameters of the Von Bertalanffy growth function (VBFG):

$$
\mathrm{L}_{t}=\mathrm{L}_{\infty} \cdot\left(1-\mathrm{e}^{-K\left(t-t_{0}\right)}\right)
$$

where $\mathrm{L}_{t}$ is the length at age $t, \mathrm{~L}_{\infty}$ is the predicted asymptotic length and $K$ is the growth coefficient. A non-linear least square regression procedure, using a Quasi-Newton algorithm, was used to estimate parameters of VBFG. The distance of the first translucent ring from the core was used to assign the fish birth date to April or October when the spawning peaks of the species occurred. The monthly timing of ring formation was analysed using the percentage of otoliths with a translucent zone at the edge in the period of capture.

\section{RESULTS}

Out of the total number of individual sampled (n $=444), 4.8 \%$ were undetermined, $44.1 \%$ males, $44.3 \%$ females and $6.8 \%$ intersexes. Fish length ranged between 9.0 and $33.5 \mathrm{~cm}$ TL and showed a polymodal distribution (Fig. 1). Net selectivity determined the occurrence of a main cohort which comprised specimens between 23 and $32 \mathrm{~cm}$ TL.

\section{Reproduction}

The trend of GSI during the year showed two distinct spawning periods: one in spring and the other

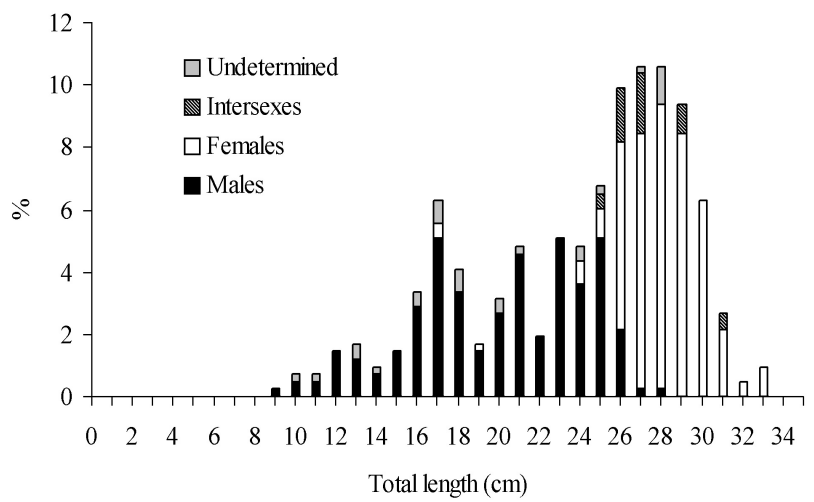

FIG. 1. - Length frequency distribution of Sarpa salpa, sampled from March 1999 to January 2002 in the central Mediterranean Sea, showing the composition according to sex.

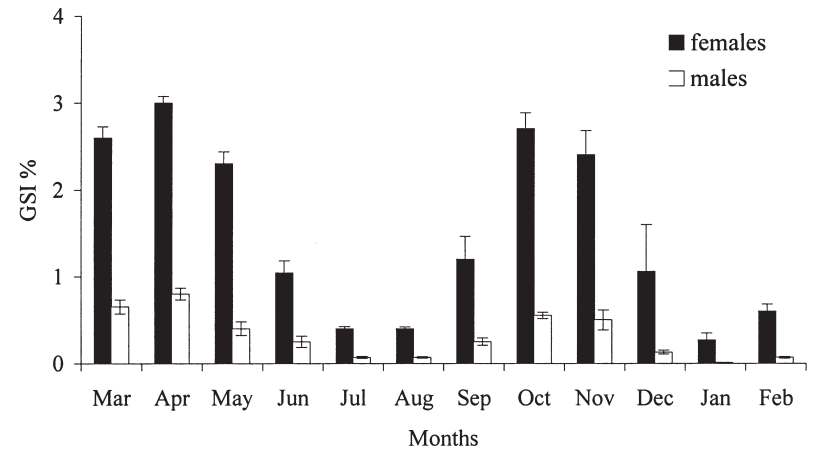

FIG. 2. - GSI monthly values of Sarpa salpa in the central Mediterranean Sea considering only the specimens that had reached the first maturity size. Error bars indicate the standard errors.
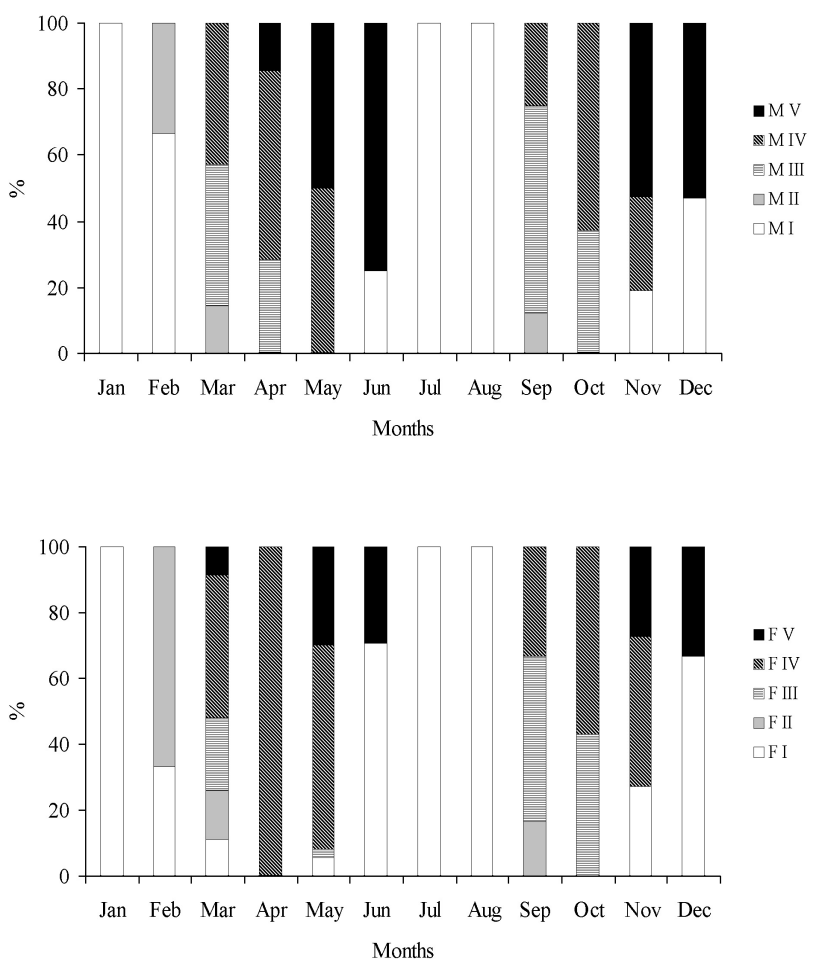

FIG. 3. - Monthly composition of gonad stages of Sarpa salpa in the central Mediterranean Sea. The maturity stages were identified following the scale for partial spawners developed by Holden and Raitt (1974).

in autumn (Fig. 2). In summer, GSI values reached their minimum for both sexes. This reproductive pattern was also confirmed by the macroscopic analysis of gonads, which indicated two main reproductive periods of salema (Fig. 3).

The sex change process occurred over $24 \mathrm{~cm}$. The size range of intersex individuals extended from $24 \mathrm{~cm}$ to $31 \mathrm{~cm}$ (Fig. 1) and corresponded to a wide range of ages ( $3-7$ years).

In the sample population, some small sized females $(17 \mathrm{~cm})$ were also observed (Fig. 1). The percentage of "undetermined" specimens varied 


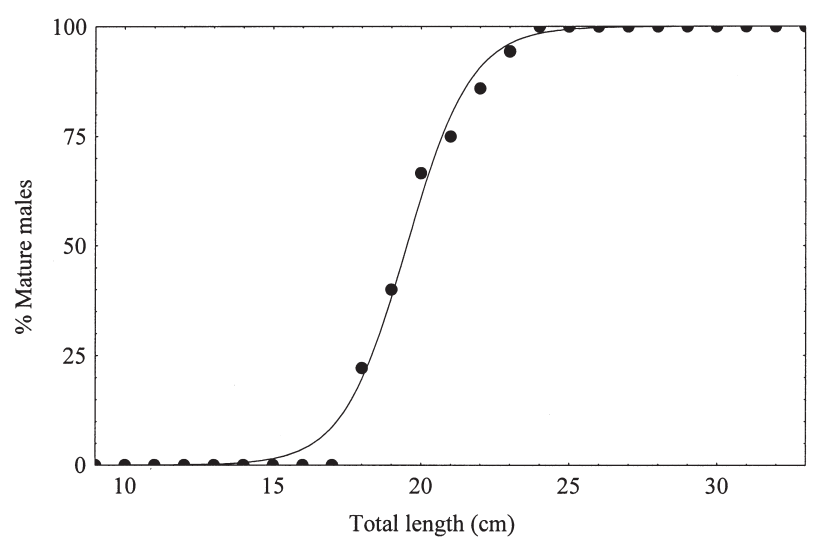

FIG. 4. - Size at maturity of Sarpa salpa males $(\mathrm{n}=76)$ in the central Mediterranean Sea.

irregularly: up to $20 \mathrm{~cm}$ length, the occurrence of these individuals could be related to the presence of gonads which were not yet differentiated, while larger undetermined specimens were found in the initial period of the sex change process when the testicular tissue is regressing, but the ovarian area has not yet begun to develop (as observed by Lepori, 1980).

Size at maturity $\left(\mathrm{L}_{50}\right)$ of this population of Sarpa salpa was calculated considering only the specimens which were caught in spring and autumn (reproductive seasons) and was $19.51 \mathrm{~cm}$ (Fig. 4). Almost all the individuals were males. All the females caught during the spawning period over 26 $\mathrm{cm}$ long were mature.

\section{Age and growth}

Otoliths showed a regular pattern of opaque and translucent rings indicating a seasonal pattern in ring formation. The analysis of the otolith edge, carried out on 408 specimens (36 were damaged or unreadable), showed (Fig. 5) an increase in the percentage of otoliths with translucent edges from July $(0 \%)$ to January $(91.7 \%)$.

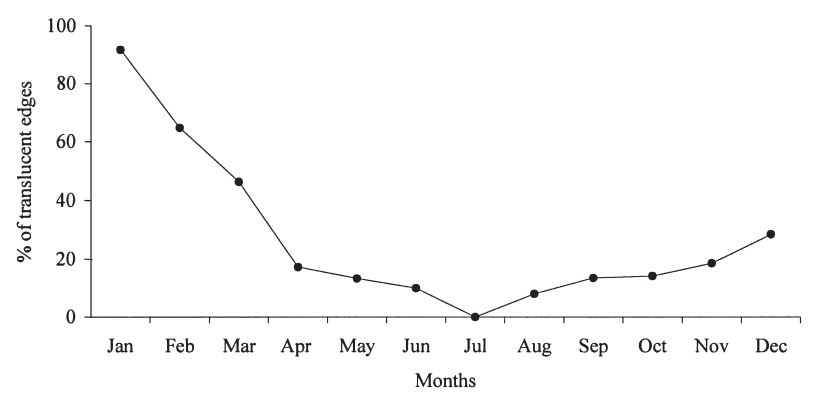

FIG. 5. - Percentages of monthly deposition of translucent ring on the otolith edge of Sarpa salpa $(\mathrm{n}=408)$ in the central Mediterranean Sea. Translucent zones were mainly formed during winter.

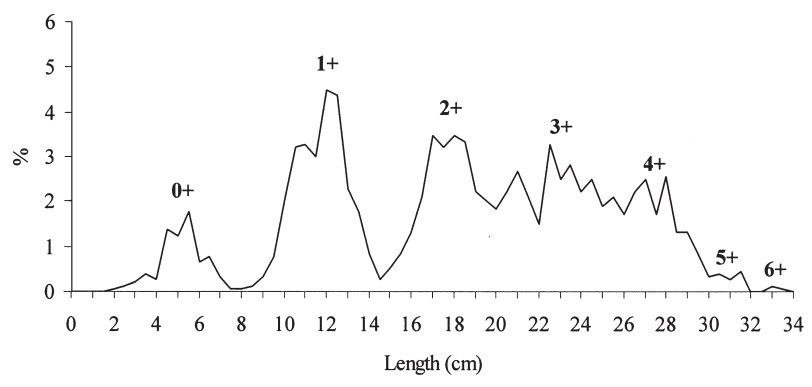

FIG. 6. - Frequency distribution of lengths-at-age of winter rings of Sarpa salpa, carried out on 408 specimens, in the central Mediterranean Sea. The first peak $(0+)$ was due to individuals of an estimated age of 4 months taking 1 October as their birthday. The peak 1+ was due to individuals born both in April (relative age: 10 months) and autumn (relative age: 14 months).

Fish length and otolith length appeared positively correlated by a linear relationship $(\mathrm{y}=83.51 \mathrm{x}-$ 41.094; $\left.\mathrm{R}^{2}=0.89 ; \mathrm{P}<0.01\right)$. According to this model, the biological intercept $\left(\mathrm{O}_{o}\right)$ of Campana's equation $\left(\mathrm{L}_{o}=6.5 \mathrm{~mm} \mathrm{TL}\right)$ was $0.57 \mathrm{~mm}$. The proportionality between fish size and otolith length allowed us to estimate the age-length key as shown in Table 3. The distribution of lengths-at-age was bimodal and showed several peaks corresponding to the various age classes (Fig. 6). As Sarpa salpa showed two distinct spawning periods (one in spring and the other in autumn), the age-length key was built using two different birth dates (either 1 April or 1 October respectively). Then, to assign a birthday to each individual, the position of the first winter ring was considered.

Two different otolith typologies were identified according to the distance of the first winter ring from the nucleus. A group of otoliths showed a well defined translucent ring close to the nucleus, so that the lengths-at-age ranged between 4 and $7 \mathrm{~cm}$ (Fig. $6)$. In a second group the first winter ring was further from the nucleus and the lengths-at-age were between 10 and $14 \mathrm{~cm}$ (Fig. 6). According to the spawning period of Sarpa salpa in the study area, the first group of otoliths seemed to be related to individuals born in autumn (1 October) which laid down their first winter ring after four months, while the second group would be due to individuals born in spring (1 April) which formed their first winter ring after ten months. The latter, together with 14 month old individuals (born in the previous autumn) formed the peak $1+$ due to compensatory growth occurring in the first year, which made it impossible to distinguish between these individuals graphically (Fig. 6).

The age at length values were then turned into year fractions when the Von Bertalanffy growth 
TABLE 3. - Age-length key (back-calculated lengths-at-age).

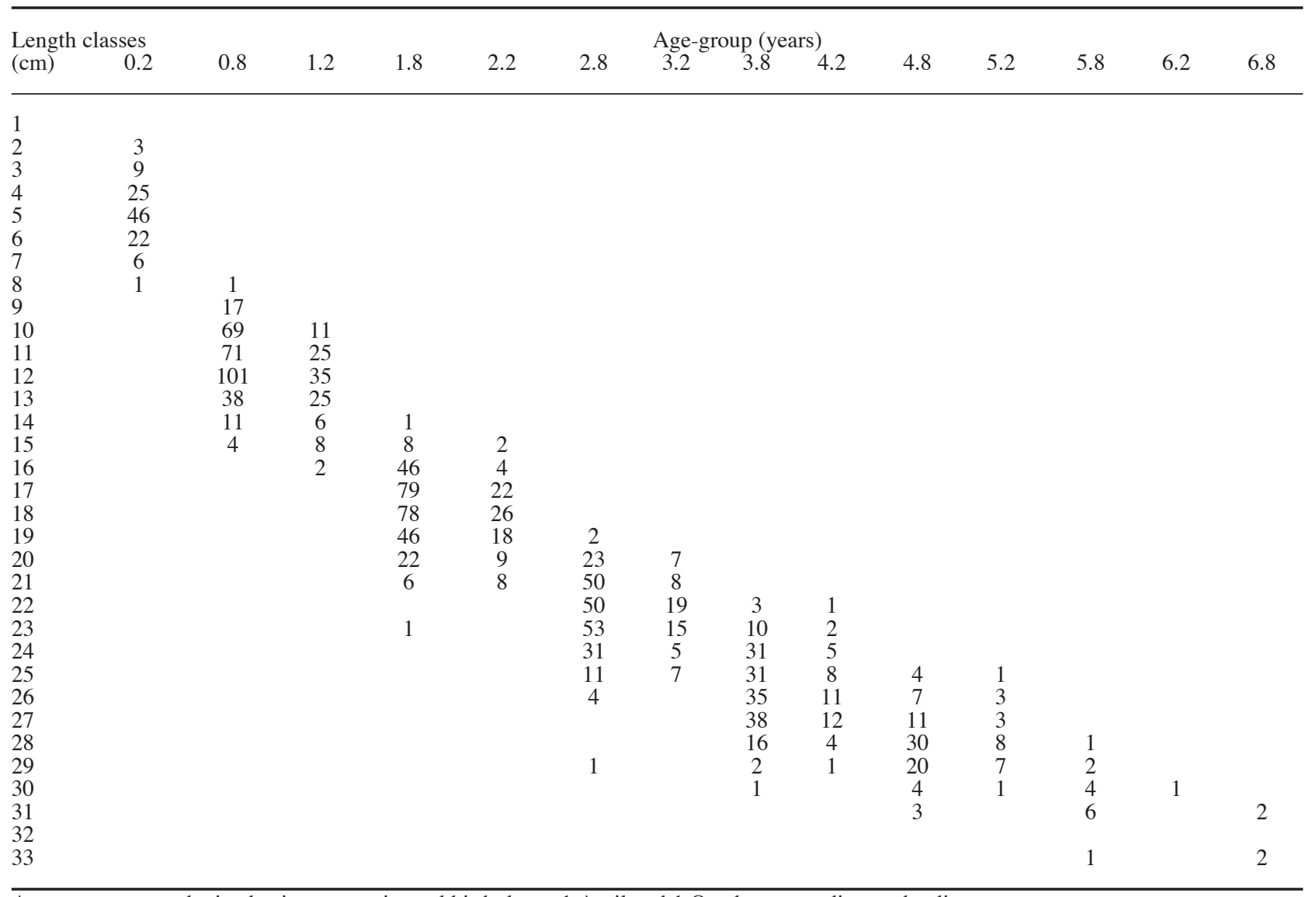

Age groups were obtained using two estimated birth dates: 1 April and 1 October, according to the distance of the first winter ring (laid down in January as shown in Fig. 5) from the otolith nucleus.

curve was described (Fig. 7). In this study, individuals aged 0 to 7 years were recorded. The parameters of the Von Bertalanffy growth equation obtained from these data are the following: $\mathrm{L}_{\infty}=37.27 \mathrm{~cm} ; \mathrm{K}$ $=0.27$ year $^{-1} ; \mathrm{t}_{0}=-0.53$ year and $\mathrm{R}^{2}=0.97$ (Fig. 7).

A T-student test showed that the value of the slope $(b=3.04)$ of the length-weight relationship

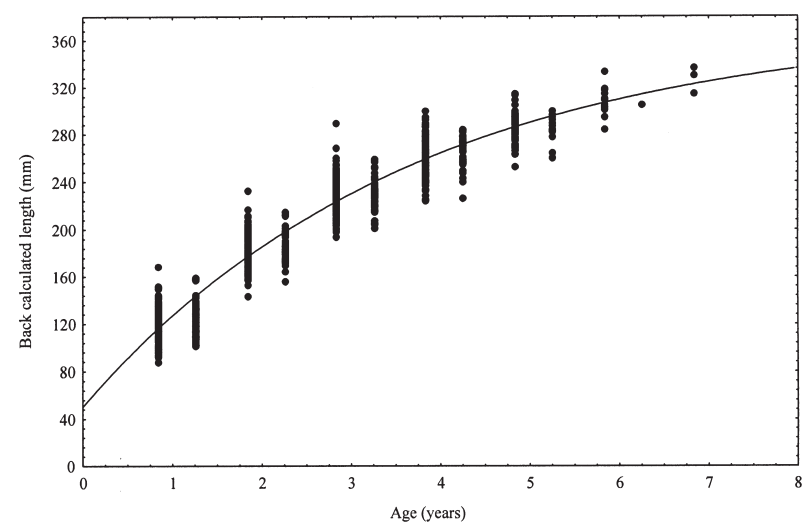

FIG. 7. - Von Bertalanffy growth curve of Sarpa salpa in the central Mediterranean Sea: $\mathrm{L}_{\infty}=37.27 \mathrm{~cm}, \mathrm{~K}=0.27$ year ${ }^{-1}$ and $\mathrm{t}_{0}=-0.53$ year
$\left(\mathrm{W}=0.0128 \mathrm{TL}^{3.043}\right)$ was not statistically different from $3(\mathrm{P}=0.84 ; \mathrm{t}=0.19)$. It proved that salema grow in an isometric way.

\section{DISCUSSION}

Salema's trophic role in coastal ecosystems was quite well understood, but few studies in the past have researched into the biological parameters of this species, especially in the Mediterranean. Therefore, in this study we tried to furnish new data on its life cycle.

Analysis of gonads confirmed that Sarpa salpa is a protandrous hermaphrodite species; therefore, it changes sex from male to female during its life. Proterandric hermaphroditism in salema has already been observed in the Mediterranean sea (Sardinia: Lissia-Frau, 1966; Lissia-Frau and Casu, 1968), in the eastern Atlantic Ocean (Canarian Archipelago: Mendez-Villamil et al., 2002), and in the western Indian Ocean (South Africa: Van der Walt and Mann, 1998). The existence of intersex 
specimens also confirms that the sex change process is a gradual phenomenon in the protandrous species (Lepori, 1980).

The sex change process may take place within a wide size range $(24-31 \mathrm{~cm})$, which corresponds to 3 to 7 year old individuals. This suggests that this process does not occur simultaneously for all males. In addition, some small sized females were observed in this population as reported on the coasts around Sardinia (Lissia Frau, 1966).

Along the central western coasts of Italy, salema spawn during two periods of the year, spring (March-May) and autumn (September-November). A similar reproductive cycle has been observed in the western Mediterranean (Corbera et al., 1998), while along the Tunisian waters (Sellami and Bruslè, 1975; Anato and Ktari, 1983), and in the Canary Islands (Mendez-Villamil et al., 2001), salema spawn during a single period that extends throughout the autumn and winter months.

The size-at-maturity of males $(19.5 \mathrm{~cm})$ didn't differ significantly from the value observed in the Adriatic Sea (19.2 cm, D'Ancona, 1949a), whereas it was smaller than the value recorded in the Canary Islands (22.6 cm: Mendez-Villamil et al., 2002).

Salema otoliths showed a clear seasonal pattern of depositing translucent and opaque rings. A peak of translucent rings occurred during the winter months, January to February, while the percentage of otoliths with opaque margins reached the highest values during the summer months (July to August). These differences appeared to be related to the seasonal change in water temperature which ranged from $13{ }^{\circ} \mathrm{C}$ in January to $25^{\circ} \mathrm{C}$ in August.

Length-at-age 1 showed a bimodal frequency distribution, which was expected considering the two spawning peaks of salema in the study area. This allowed us to assign each individual with a birthday, either 1 October or 1 April, based on the distance from the nucleus of the first winter ring in the otoliths.

Individuals born in autumn reached $5-6 \mathrm{~cm}$ in January and $12 \mathrm{~cm}$ the following year as observed for individuals born in spring. Therefore, compensatory growth occurred for this latter group of fish during their first year of life. The growth rate decreased when fish attained sexual maturity at the end of their second year of life as a result of the increased energy demand related to developing gonads. The oldest age estimate obtained in this study was seven years for females with a $33 \mathrm{~cm} \mathrm{TL}$. The growth performance of salema in the Mediterranean $(\phi=2.59)$, esti- mated using the $\phi$ index of Munro and Pauly (1983), showed a growth rate dissimilar to those reported from South Africa $(\phi=4.44$ : Van der Walt and Beckley, 1997), and the Canarian Archipelago ( $\phi=$ 2.68: Mendez-Villamil et al., 2001). In the latter area salema seems to reach a larger length-at-age than in the Mediterranean. This is observed in many fish species that are generally smaller in the Mediterranean than in the eastern Atlantic.

The length-weight relationship showed isometric growth for the Latium population of Sarpa salpa (b $=3.04 ; \mathrm{P}=0.84 ; \mathrm{t}=0.19)$; the same conclusion was reached by Mendez-Villamil et al. (2001), for the population of the Canarian archipelago.

The data obtained represents only a first step in the study of Sarpa salpa as it is important to analyse the influence that salema, one of the most abundant species in areas characterised by rocky bottoms and seagrass meadows (Verlaque, 1990; Dulcic et al., 1997; Francour, 1997), exerts on the coastal fish assemblages.

\section{REFERENCES}

Anato, C. B and M.H. Ktari. - 1983. Reproduction de Boops boops (Linné, 1758) et de Sarpa salpa (Linnè, 1758), Poissons Téléostéens, Sparidés du Golfe de Tunis. Bull. Inst. Nat. Scient. Tech. Océanogr. Pèche, Salammbo, 10: 49-53.

Antolic, B., B. Skaramuca, A. Span, D. Musin and J. Sanko-Njire. - 1994. Food and feeding habits of a herbivore fish Sarpa salpa (L.) (Teleostei, Sparidae) in the southern Adriatic (Croatia). Acta Adriat. 35(1-2): 45-52.

Bortoluzzi, G., F. Frascari, S. Guerzoni, N. Incremona, M. Ravaioli and G. Rovatti. - 1982. Some sedimentological and chemical features of the seafloor in front of the Tiber river. Geog. Fis. Dinam. Quat., 5: 120-128.

Campana, S.E. - 1990. How reliable are growth back-calculations based on otoliths? Can. J. Fish. Aquat. Sci., 47: 2219-2227.

Corbera, J., A. Sabatés and A. Garcia-Rubies. - 1998. Peces de Mar de la Péninsula iberica. Ed. Planeta, Barcelona.

D’Ancona, U. - 1949a. Il differenziamento della gonade e l'inversione sessuale degli Sparidi. Arch. Ocean. Limnol., pp. 97-165.

Dulcic, J., M. Kraljevic, B. Grbec and A. Pallaoro. - 1997. Composition and temporal fluctuations of inshore juvenile fish populations in the Kornati Arcipelago, eastern middle Adriatic. Mar. Biol., 129(2): 267-277.

Francour, P. - 1997. Fish assemblages of Posidonia oceanica beds at Port-Cros (France, NW Mediterranean): Assessment of composition and long-term fluctuations by visual census. Mar. Ecol., 18(2): 157-173.

Gerking, S.D. - 1984. Assimilation and maintenance ration of an herbivorous fish, Sarpa salpa, feeding on a green alga. Trans. Am. Fish. Soc., 113: 378-387.

Gerking, S.D. - 1994. Feeding ecology of fish, pp. 57-88. San Diego: Academic Press, California.

Havelange, S., G.Lepoint, P. Dauby and J-M. Bouquegneau. 1997. Feeding of the sparid fish Sarpa salpa in a seagrass ecosystem. Mar. Ecol., 18(4): 289-297.

Hiatt, R.W. and D.W. Strasburg. - 1960. Ecological relationship of the fish fauna on coral reefs of the Marshall Islands. Ecol. Monogr., 30: 65-127.

Holden, M.J. and D.F.S. Raitt. - 1974. Manual of fisheries science. Part 2. Methods of resource investigation and their application. FAO Fish. Tech. Rep., (115): Rev. 1, 214 pp.

Hunt, J.J. - 1979. Back-calculation of length-at-age from otoliths 
for silver hake of the Scotian shelf. ICNAF Sel. Pap., No. 5: $11-17$.

Lepori, N.G. - 1980. Sex differentiation, hermaphroditism and intersexuality in vertebrates including man, pp. 18-26, 223232, 259-268. Piccin Medical Books, Padua.

Lissia Frau, A.M. - 1966. Ricerche sul differenziamento sessuale di Boops salpa (L.) (Teleostei, Sparidae). Atti Accad. Gioenia Sci. Nat. 6 ser., 18: 165-174.

Lissia Frau, A. M. and S. Casu. - 1968. Il processo gonado genetico in alcune specie di Sparidi (Teleostei, Perciformes). Studi Sassaresi, 1: 1-23.

Lo Bianco, S. - 1931-1956. Uova, larve e stadi giovanili di teleosteo. Fauna e flora del golfo di Napoli, pp. 368-371. Stazione zoologica di Napoli e UNESCO (eds.).

Malo-Michèle, M. - 1977. Contribution a l'étude histologique de la gonade, en particulier de l'ovaire, chez la Saupe, Boops salpa (L.) (Teleosteen, Sparidae). Donnés nouvelles sur son type d'hermaphrodisme. Invest. Pesq. 41(1): 165-183.

Mendez-Villamil, M., J. G. Pajuelo, J. M. Lorenzo, J. Coca and A.Ramos. - 2001. Age and growth of the salema, Sarpa salpa (Osteichthyes, Sparidae) off the Canary Islands (East-central Atlantic). Arch. Fish. Mar. Res., 49(2): 139-148.

Mendez-Villamil, M., J. M. Lorenzo, J. G. Pajuelo, A. Ramos and J. Coca. - 2002. Aspects of the history of the salema, Sarpa salpa (Pisces, Sparidae), off the Canarian Arcipelago (centraleast Atlantic). Environ. Biol. Fish., 63: 183-192.

Munro, J.L. and D. Pauli. - 1983. A simple method for comparing the growth of fishes and invertebrates. Fishbyte, 1: 5-6.

Pinnegar, J. K. and N. V. Polunin. - 2000. Contributions of stableisotope data to elucidating food webs of Mediterranean rocky littoral fishes. Oecologia, 122(3): 399-409.

Ruitton, S., P. Francour and C. F. Boudouresque. - 2000 Relationships between Algae, Benthic Herbivorous Invertebrates and Fishes in Rocky Sublittoral Communities of a Temperate Sea (Mediterranean). Estuar. Coast. Shelf Sci., 50(2): $217-230$

Sanchez Lizaso, J. L. and A. A. Ramos Espla. - 1994. Grazing on the seagrass Posidonia oceanica in the marine reserve of Tabarca, Spain. Invest. Mar. CICIMAR. La Paz, 9(2): 103-108.

Sellami, A. and J. Bruslé. - 1975. Contribution a l'étude de la sexualité de la saupe Boops salpa Linnaeus 1758 (téléostéen Sparidae) des cotes de Tunisine. Vie Milieu, 25: 261-275.

Van der Walt, B. A. and L. E. Beckley. - 1997. Age and growth of Sarpa salpa (Pisces: Sparidae) off the east coast of South Africa. Fish. Res., 31: 241-248.

Van der Walt, B. A. and B. Q. Mann. - 1998. Aspects of the reproductive biology of Sarpa salpa (Pisces: Sparidae) off the east coast of South Africa. S. Afr. J. Zool., 33(4): 241-248.

Verlaque, M. - 1990. Relationship between Sarpa salpa (L.) (Teleostei, Sparidae), other browser fishes, and the Mediterranean algal phytobenthos. Oceanol. acta, 13(3): 373-388.

Scient. ed.: E. Massutí 